Historic, archived document

Do not assume content reflects current scientific knowledge, policies, or practices. 



\section{Some New Fruits Originated at the Minnesota State Fruit Breeding Farm}

\section{PLUMS}

Underwood (Minn. No. 91)-A large fruited, vigorous growing, early maturing variety, especially promising on account of its size, red color, earliness and high quality.

Tonka (Minn. No. 21)-An extremely productive variety, producing large, round, red fruits of firm flesh and good quality.

Red Wing (Minn. No. 12) - One of the largest fruited plums produced at the Fruit Breeding Farm, ripens mid-season, with beautiful red freestone fruits of high quality.

Monitor (Minn. No. 70) - A late mid-season variety, with a vigorous, well shaped tree, producing large, red, firm fleshed fruits, of fair to good quality.

Mound (Minn. No. 50) - A very large fruited variety, bearing heavy annual crops of firm fleshed fruits of fair quality.

Anoka (Minn. No. 118) - A moderate sized, productive tree, bearing large dark red medium sized fruits, ripening the first of September.

Golden Rod (Minn. No. 120) - A vigorous variety bearing pure yellow fruits of firm flesh and fair quality; promising as a market and home variety; season, late August.

Elliott (Minn. No. 8) - A strong growing variety producing large, highly colored red fruits of good quality, ripening the first week in September; one of the most promising of the late plums.

Winona (Minn. No. 30) - This variety is a vigorous grower, produces fruits of highest quality, yellow with a red blush, somewhat subject to brown rot.

La Crescent (Minn. No. 109)--An extremely vigorous tree, baaring pure yellow fruits of highest quality and delicate texture; most promising as an early home variety, but too tencer for shịpping.

Hennepin (Minn. No. 132) - A large, dark red fruit, with deep red or purple flesh; excellent for canning; mid-season.

Waconia (Minn. No. 10) - A medium to large fruited variety, with heart-shaped fruits, ripening late mid-season; productive and good quality.

\section{CHERRY-PLUMS}

Zumbra-A hybrid containing the blood of the sweet cherry, wild pin cherry and sandcherry. It is a dwarf tree of the type of Sapa or Opata, a very productive bearer. Quality is good, but should be thoroughly ripened before picking. Late mid-season.

St. Anthony (Minn. No. 145) - A dwarf variety, producing heavily of dark purple fruits, with purple flesh, ripening about September 1st; quality good when fully ripe; excellent for canning.

\section{ORNAMENTALS}

Newport (Minn. No. 116) - A beautiful dark purple-leaved variety of plum carrying its rich color throughout the season; fruits below medium in size, and of little value.

Manitou (Minn. No. 7)-An early spring-flowering tree or shrub, dwarf to medium size, producing great masses of bloom but no fruit. A hardy cross between Siberian almond and peach. 
